Image and Man - Correlations, eds. Marcin Godawa, Bojan Žalec, Krakow 2020, pp. 95-102.

DOI: http://dx.doi.org/10.15633/9788374386807.09

Veronika Beliaeva-Saczuk

Peter the Great Museum of Anthropology and Ethnography (the Kunstkamera) of the Russian Academy of Science, Russia

\title{
Goddess on a Rock - Buddhistic Sacred Places Dedicated to the White Tara and the Green Tara in the Okian Region, the Republic of Buryatia, the Russian Federation
}

The Okian region (bur. Acha, also Oka, Okiyskij kraj) is one of the furthest and most difficult regions to reach in the Republic of Buryatia. Despite an increasing number of ethnological expeditions to Oka some aspects of the Okists' traditional culture, including the Buriats and Sojots' beliefs still remain poorly explored. The Okists' contemporary religious system is based on Tibetan Buddhism therefore in the Okian region along with temples, many other Buddhistic sacred places exist. Two of them, dedicated to the White Tara and the Green Tara, play an exceptional role in local religious life. This article has been written as a result of my ethnological expeditions to those places in 2014 and 2015.

I.

In order to capture ethno- and religious specifics, geographical and social contexts ought to be evoked. The Okian region, the Western one in the Republic of Buryatia, covers $26012 \mathrm{sq}$. km which is inhabited by 5400 individuals only (Бурятстат 2016) due to severe natural and climatic conditions as well as its isolation. It is situated on a plateau at an altitude of 1600-2100 m. above sea level and surrounded by the high Eastern Sayan 
Mountains. Short cool summers, long frosty winters and permafrost confine the economy to breeding whereas long distances to towns, the lack of sufficient roads retain social stability, culture and religion. The region is inhabited by two autochtonous ethnoses - the Soyots and Buryats. The Soyots, whose population is 3079 people (2011), are neolithic Sayan population's descendants who remained under Turkish and Mongolian influences and despite their traditional shamanism, at present they confess to Buddhism owing to mixed marriages and an extinction of shamans in the 1940s. The Buryats appeared in the Okian region in the middle of the $17^{\text {th }}$ century. Their culminating wave flooded the region one century later, partly as a consequence of the tightening of the Russian-Mongolian border (Павлинская 2002, 52). Nowadays, the Buryats 'strength constitutes around 40 percent of the whole regional society.

The history of Okian Buddhism originates from their religious identity. According to the local traditions the successful mission of the Dalaylama's emissars is marked by the Buddhistic seals [tamgas], the symbols of Buddhistic domination, nearby the Sayans settlement, in the Western part of Mongolzhon valley (Beliaeva-Saczuk, 2014, 2015; cf. Лбова, Хамзина 1999, 141, Сыртыпова 2007). The fact that contemporary Okian Buddhism contains less elements of shamanism than in other regions of Buryatia, can be broadly explained. First of all, there was a Buddhistic monastery in Oka, [Zhelgensky datsan] where not only religious knowledge but also lay education for children along with teaching Tibetan, Mongolian, Russian and Latin-were provided. The monastery was well known for producing religious and daily handcrafts made out of metal or wood as well as for practice of emchi-lamas, the medics owning numerous clinics located beside holy springs too. The respect for the lamas, like Agvan Dorokhinov, built up the position of Buddhism preventing the society from shamans' activities.

The factor influencing the contemporary Okian Buddhism was extremely strong repressions in the 1920 s and 1930 imposed on the whole local society, including Buddhistic monks and shamans in response to their resistance. Contrary to other regions where some part of shamans was allowed to offer their own and also Buddhistic services, having replaced lamas, all the shamans in Oka were persecuted while a few of the Okian lamas having come back from lagers in the 1950 s continued their work. This development is crowned by Fiodor Samayev (lama Danzan-Khaybzun), the Okian, who after 1990 gave his great contribution to the renascence of the Tibetan Buddhism 
in Russia. From among his achievements some should be underlined as follows: the efforts for the return of a datsan in Saint Petersburg to the faithful and its new inauguration, the Buddhistic revival in the Okian and Tunkian regions, the establishment of the ecological organization Ahalar and his involvement in the process of regarding the Soyots' as a distinct ethnos. In spite of his unexpected death in 2005 he is still perceived as a teacher and an embodiment of Agvan Dorzhiyev, a Buddhistic activist from the $19^{\text {th }}$ and $20^{\text {th }}$ centuries. Almost all of my interlocutors admitted to following Samayev's teaching.

\section{II.}

Against this background the significant role of the White and the Green Tara can be presented. Both figures are comprehended as an emanation of Tara the Liberator-a female bodhisattva ${ }^{1}$ and a personification of compassion and mercy. The White Tara [Tib. sgrol-dkar-ma, Bur. Sagan Dara Ekhe] is a deity of meditation, long life, chastity and transcendental wisdom. She is portrayed as a young woman, crowned and decorated, sitting in a lotus position with her right hand showing a sign of compassion and mercy [warada mudra], that means that she is keeping her fingers downward and the inner part of her palm to the front whilst her left hand performs a sign of teaching [jnani mudra] with a lotus flower. An outstanding feature is her seven eyes - three on her face, two respectively on each of her palms and feet-which enable her to recognize suffering. She is said to be represented by various historical persons, for example, the tzarina Catherine II, due to her approval to Buddhism in Russia, as well as to distribute her most effective help to those in serious health conditions (Обитель милосердия 2015, 251-256).

The Green Tara [Tib. sgrol-ljang-ma, Bur. Nogoon Dara Eche] is depicted as a young woman of green skin sitting in a special latitasana position, that is with one leg lowered to a small lotus flower, which symbolises her immediate readiness for motherly help to every sensitive being. Her right

1 Bodhisattva - 'a hero of mind of illumination' is a being possesing a desire to reach the state of illumination in everybody's interest. This attitude is based on their will to liberate all the sensitive beings from suffering and reincarnation. 
hand expresses the gesture of warada mudra while left one - the sign of care [abhaja mudra] in a form of a lifted palm with straightened fingers. She holds opening lotus flowers or lilies with long blue petals. The goddess, highly respected in Buryat Buddhism, is believed to supply wisdom and to erase fear and other impediments, like demons, from the way of illumination. In addition, her care for families was appreciated, especially for children, women wishing to become mothers and the expectant women. A well-known legend presents her vow to remain in a female body until all the beings reach the illumination which suggests its universal accessibility regardless of sex or descent. The Green Tara's embodiments were noticed too, for example Dondogdulam [Ekch Dagina], the last theocratic Mongolian ruler's wife (Обитель милосердия 2015, 258-267).

Although both places, dedicated to both Taras, pertain to the essence of the Okian Buddhists' life, this one connected with the White Tara distinguishes itself by its age and local popularity until now. The White Taras sacred site, situated at the summit of the Sakhir-baysa mountain, to the North from the centre of the Okian region [the settlement Orlik] is a distance of $25 \mathrm{~km}$ along an inconvenient road from the nearest hamlet is completely empty. The main cultic object is a granitic slab which has a size of $130 \times$ $160 \times 6 \mathrm{~cm}$ on which the figure of the White Tara has been engraved. Its fragment, with the motive of a lotus throne, has been placed at the bottom of the block because it was broken off when being transported, according to local traditions (Культовые обьекты Окинского района 2013, 28-29). This canonical image had been painted with natural, mineral dyes but around five years ago it was re-painted by school children with an oil-based dye on request of an Okian lama coming from the outside [Mongolia]. The action provoked strong discontent among the people, mainly of intelligentsia, which is justified by the fact that delicate mineral substances gave the effect of non exaggerated brightness being as close as possible to nature in line with the inhabitants' general attitude. It is interesting that within such a 'restoration' the effigy was even changed more. Namely, the oil-based dye covering the dainty grooves of the slab, where as per canons, the White Tara's bared breasts with their nipples had been carefully sculptured, thus, all the details, regarded as improper, are hidden now. In my opinion, this was triggered by some puritanical communistic morality implemented in the Soviet times which continuously had an influence on the contemporary Russian way of thinking no matter their descent or belief. 
The issue of origins and authorship is deeply interesting. In one of the versions it is acknowledged that the slab had been brought from Tibet or Mongolia in the 1870 os and sculptured by artists from there. I was informed that the breaking off of its fragment happened, when being transported to Oka. In the other version the making of the image is ascribed to emchi-lama Agvan Dorokhinov from the same Okian region. Also the question where the sculpture was exposed before is discussed from the point that it rested at Zhelgensky datsan until it was closed by the communists (1928) while it appeared from a few publications on the White Tara that her figure was located in a valley near the Sakhir-baysa mountain in the terrain occupied by Dorokhinov (Культовые обьекты Окинского района 2013, Сыртыпова 2007, Хонгодоры 2013). Nevertheless, the placement of the object into its present-day spot in the 1930s was proved to be as a result of the escalation of religious persecution in the USSR. At that time the slab was put onto the top of the Sakhir-baysa mountain face down in order to prevent destruction. In the 1940 os it was found by a boy who was pasturing sheep, he reported it to his parents but, because of fear, was forced to keep it a secret. Not until the collapse of the USSR as an old man he told the Okians about his finding. Accompanied by the clergy and using the correct rituals the slab was then solemnly exalted and this place was regarded as the Tara's new residence. Nearby her image a new simple altar was raised where milk, sweets and butter were offered when sacrificial khadaks [sashes of good wishes] and zurmadahans [votive ribbons] were hung on trees. Once a year the Okians have a big celebration for the White Tara, they paint her image with mineral dyes.

The situation was changed, however, in 2011 when in the Okian region a Mongolian lama Bair started to act. He is firmly supported by the main Buddhist organisation in Buryatia - the Traditional Sangha of Russia, of which at the head, Damba Ayusheyev bears the name of Khambo-lama and claims to preside over all the Buddhists in Russia, however, he only leads most of the Buryat Buddhists. Within the doctrine of the promotion of Oka as Little Tibet with its heavenly inhabitants a chapel [dugan] was built (2011) into which the Tara's image was moved. The front of the goddess was turned from facing the South-East to facing the West so that she looks over the Oka river flowing just below the Sachir-bajsa mountain, on the only way leading to this site, two new sacred objects were placed, namely a big tree called the Mother-Tree [Ezhy Modon] and the Mother-Mountain [Ezhy Khad], 
so as to make the whole place more attractive and effective. Nowadays, petitions for posterity are addressed to the Tara as those for an ability to give birth to the Mother-Tree and Mother-Mountain.

The people's reaction to the changes tells us a lot about their religiousness. While the Mother-Tree was generally accepted in shamanism and Okian Buddhism, the Mother-Mountain was rejected. The statue of the Mother-Mountain is a huge stone in the shape of a sitting woman dressed in traditional Mongolian cloth [degel] that suggests a figure of an infant held by a woman. From the outside, the dress in the form of a female head, only remains visible, is supplemented by the appearance of a Buryat woman, painted weakly with an olive-based dye. The object is covered by a wooden roof and surrounded by khadaks and zurmadahans. According to my research, this place seems to be worshipped yet only in accompaniment to the main temple. None of my seven companions praised the Mother-Mountain by oblation or by a traditional clockwise procession but they kept looking at it with curiosity. Many informants told me that the stone was unduly painted, mainly in the sense that the red mouths were too red and that the idea of dressing was pointless, this can be explained by the fact that too much money was spent on the silky cloth instead of allocating it to more important aims and by their conviction that dressing a stone is unnatural. Not denying the sacred character of the stone they are living very close to the natural demand for a strict bond between nature and holy places (Beliaeva-Saczuk, 2015).

The person of lama Bair allows us to proceed to the Green Tara whom he intensively promoted. Visiting Dzhe Khenpo, the highest Buddhistic hierarch in Bhutan (2011), Bair found out that in the Okian region there is also supposed to be a location of the Green Tara's revelation. Having returned and asked about such a place, he met Zhugdyr Mandagayev from the region, a man at the age of 92, who admitted that when he was 10 years old he had seen the Green Tara descending from the heavens onto the Khara Khoshuun mountain, in the settlement of Mongolzhon. Banned by his parents to spread the message he was personally sure of her assistance during the World War II. He showed the place of the Tara's revelation to Bair which in 2013 along with the previous location was officially approved by the delegation from Khambo-lama (Белая и Зеленая Тары 2013). As a result, at that spot the image of the Green Tara has been drawn on the rock and inside a little cave a small altar and baskets for donations have been placed. This area is 
mainly attended by families asking for posterity and also toys are collected to be given to poor children.

Two places - of the White and Green Taras lie at a distance of $10-15 \mathrm{~km}$ from each other but they are split by the Oka river, which turns intensively there. According to the locals, the goddesses are meant to be sisters who as women cannot live together in harmony this is why they are situated at two different spots. In spite of this, they both seem to give khadak one to the other (Beliaeva-Saczuk, 2015). Although the Green Tara's place is less known at the same time it is worshipped more. It stems from the fact that many Okians observe the second shape of the sitting Tara, presumably the reflection of rocky lichen, which appears above and on the left from the present one. This area is more natural and unspoilt. There are also two untouched objects: the venerated stone stairs which the goddess used to walk down towards the centre of the earth and a crack in a rock named the Mother's Womb [Ehyn Umaj]. When someone goes through it they can be cleansed from evil sins. This place is supposed to become more popular not only by virtue of the well-known Tara but mainly because it is closer to contemporary Okian Buddhism in which shamanism of the Soyots and Buryats is linked with Tibetan Buddhism. What is more, an ecological attitude along with the idea of natural life causes that the objects organised in accordance with the nature are easily accepted.

(translated by Marcin Godawa, The Pontifical University of John Paul II in Krakow, Poland)

\section{REFERENCES}

Белая и Зеленая Тары (2013): Белая и Зеленая Тары (Сагаан (Долгор) Дари Эхэ ба Ногоон (Дулма) Дара Эхэ), “Аха” № 46 (8703), 13.09.2013.

Бурятстат (2016): Территориальный орган Федеральной службы государственной статистики по Республике Бурятия, http://burstat.gks.ru/wps/wcm/connect/ rosstat_ts/burstat/ru/statistics/population/ (19.06.2016).

Горная Ока (2010): Горная Ока: справочник-путеводитель по Окинскому району Республики Бурятия, сост. А. Б. Иметхенов [и др.]; отв. ред. В. В. Горбатовский, Москва.

Культовые объекты Окинского района (2013): Культовые объекты Окинского района, сост. Ц. Б. Базарова, Орлик. 
Лбова Л. В., Хамзина Е. А. (1999), Древности Бурятии: карта археологических памятников, Улан-Удэ.

Обитель милосердия (2015): «Обитель милосердия». Искусство тибетского буддизма, ред. Ю. И. Елихина, Санкт-Петербург.

Павлинская Л. Р. (20о2), Кочевники голубых гор. Судьба традиционной культуры народов Восточных Саян в контексте взаимодействия с современностью, Санкт-Петербург.

Сыртыпова С. Д. (2007), Святыни кочевников Трансбайкалья: Традиционные культовые объекты как памятники истории и культурь, Улан-Удэ.

Хонгодоры (2013): Хонгодоры. Уулын уладай уулзалга, ред. Н. Гармаева, Улан-Удэ. Beliaeva-Saczuk (2004, 2011, 2014, 2015), the all-terrain exploration of the Okian Region. 